PONTIFÍCIA UNIVERSIDADE CATÓLICA DO RIO DE JANEIRO

ATIVAÇÃO DE MARCA ATRAVÉS DO PATROCÍNIO ESPORTIVO

Fernando Edmundo Paz

Trabalho de Conclusão de Curso

CENTRO DE CIÊNCIAS SOCIAIS - CCS

Departamento de Administração

Graduação em Administração de Empresas 


\title{
ATIVAÇÃO DE MARCA ATRAVÉS DO PATROCINIO ESPORTIVO
}

\author{
Trabalho de Conclusão de Curso
}

Trabalho de Conclusão de Curso, apresentado ao programa de graduação em Administração da PUC-Rio como requisito parcial para a obtenção do titulo de graduação em Administração.

Orientadora : Marina Frid

Rio de Janeiro

Outubro 2015 


\section{AGRADECIMENTOS}

Gostaria de agradecer à minha família, principalmente minha Mãe e meu Pai que com muita paciência e persistência conseguiram me convencer a chegar até aqui. $E$ por toda a minha formação como pessoa, que desde o meu nascimento me ensinaram valores que levarei para a vida toda como meus princípios. E um dos pilares mais importantes da minha vida, senão o mais importante foi a inserção da vida esportiva como criação do meu caráter. Amo vocês. 


\section{RESUMO}

Ter uma marca forte e com grande reconhecimento é um dos maiores anseios dos gestores de empresas em todo mundo, visto que marcas reconhecidas e consolidadas no mercado resultam em maiores ganhos e lucros para as companhias, gerando maior valor financeiro para a empresa. Assim, o objetivo do trabalho é identificar e analisar o panorama esportivo que em meio às estratégias de patrocínio esportivo das empresas que apoiam concomitantemente equipes de futebol e competições visam obter maior visibilidade para sua marca, obtendo assim, maiores retornos. Foi utilizada a metodologia de pesquisa qualitativa, que se deu através de um questionário semi-estruturado com abordagem descritiva, cuja coleta de dados se deu através de entrevistas com profissionais do mercado de marketing esportivo integrantes agências de marketing esportivo e clubes. Os gestores das corporações que optam pelo segmento desportivo apresentaram suas impressões sobre o retorno proporcionado e o retorno esperado com essa parceria. Com a análise dos resultados das pesquisas utilizadas nesse estudo percebeu-se que há grande visibilidade de marca e as consequências do patrocínio são bastante animadoras para as organizações. $O$ patrocínio beneficia tanto a organização apoiadora quanto a equipe de futebol.

Palavras - Chave: Marcas, Marketing de Ativação, Marketing Esportivo. 


\begin{abstract}
To have a strong and renowned brand is one of the greatest desires of business managers everywhere, since having renowned and solidified brands in the market lead to greater gains and profits for companies, increasing a company's financial value. Thus, the purpose of this work is to identify and analyze the sports panorama, including companies' sponsorship strategies that support both soccer teams and competitions, focused on obtaining greater brand visibility and, as a result, greater profits. A qualitative research methodology was used, by means of a semi-structured questionnaire with a descriptive approach, collecting data by interviewing sports marketing professionals working at sports marketing agencies and soccer teams. The companies' sports managers presented their impressions on actual and expected profits. By analyzing the research's results, it was concluded that sponsorships result in great brand visibility and returns are very encouraging for companies. The sponsorships benefit both the sponsoring company and the football team.
\end{abstract}

Key - Words: Brands, Activation Marketing, Sports Marketing. 


\section{Sumário}

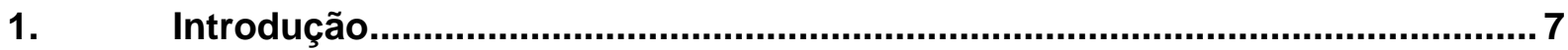

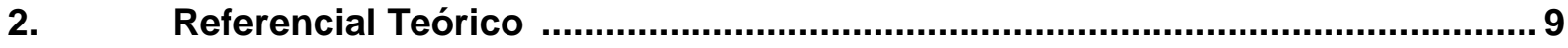

2.1. Marcas e Modelo de Avaliação de Marcas ...................................................

2.1.1 Branding, Marca e sua Importância para as Empresas ..................................... 9

2.1..2. Os Atributos da Marca (Modelo de Aaker) ..................................................... 10

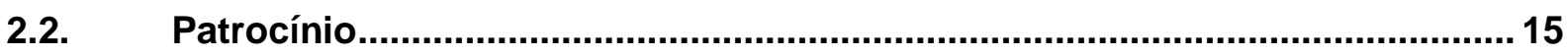

2.2.1. Objetivo das empresas patrocinadas........................................................... 16

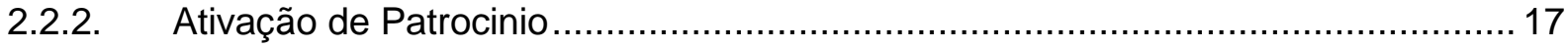

2.2.3. Relação da lembrança da marca com a medição de patrocinio ............................ 18

2.2.4. Retorno do investimento do patrocinio em marca ........................................... 19

2.3. Marketing Esportivo ................................................................................. 22

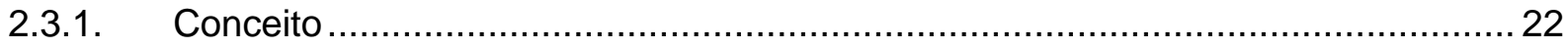

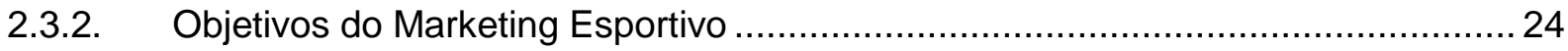

2.3.3. Marketing Esportivo no Brasil ................................................................... 25

2.3.4. Marketing de Clubes, Patrocinio, Licenciamento e Promoções de Vendas........... 27

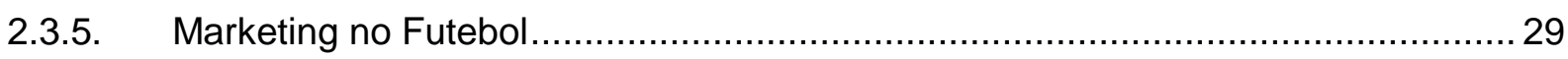

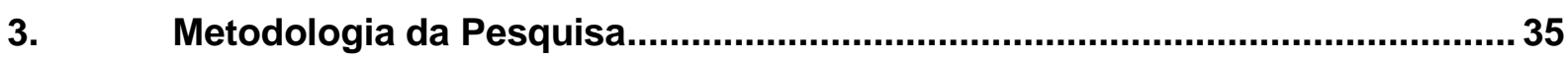

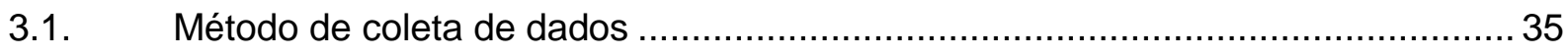

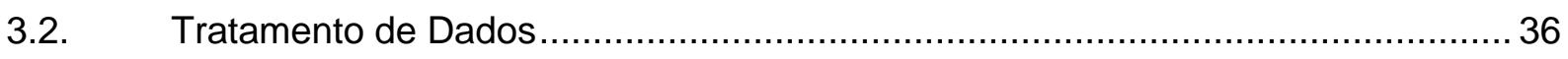

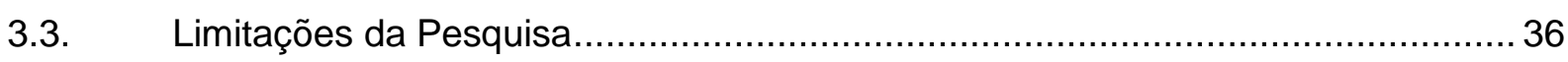

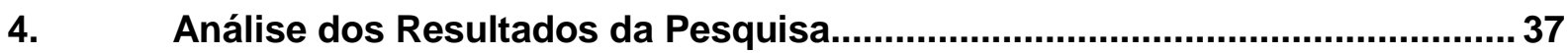

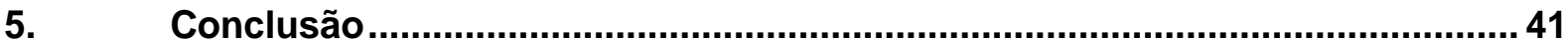

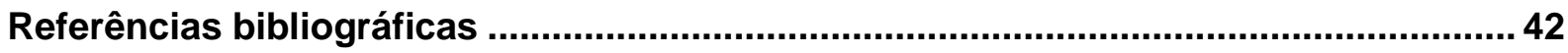


1. Introdução

Marca é um dos principais diferenciais competitivos em diversos setores da economia. Esse ativo exerce grande poder na cabeça do cliente. Uma marca consolidada leva-o a pensar nos benefícios materiais e imateriais que the serão proporcionados ao comprar determinado produto e/ou serviço. Assim sendo, podemos inferir que uma marca é um ativo intangível que pode ser visto como um vínculo de confiança entre compradores e empresas.

Com base no poder de convencimento das marcas, esta monografia objetiva estudar o mercado de patrocínios de marcas esportivas, e elucidar diferença existente entre marcas que buscam realizar ativação de patrocínio, ou seja, marcas que criam ações integradas ao patrocínio, gerando maior visibilidade deste investimento, e marcas que não realizam ativação de patrocinio. De acordo com um estudo feito pelo ITAU BBA (2014) sobre a situação financeira dos 24 clubes da primeira divisão do campeonato brasileiro, 0 faturamento dos times brasileiros com patrocínios no ano de 2013 chegou a $R \$ 471$ milhões de reais, sendo uma alta de $14 \%$ em relação à 2012. E, na Europa, só no ano de 2014, os contratos de patrocínios dos gigantes europeus chegou no valor de €405,3 milhões, segundo a European Jersey Report.

Muitos dos patrocinadores enxergam a ativação da marca nos eventos como uma oportunidade de aumentar a ligação entre a marca e seus reais consumidores e, para isso, investem em ações integradas para que a marca seja lembrada após o evento ou patrocínio em questão.

De acordo com um estudo feito pela empresa IEG (2011), 69\% das empresas norte americanas analisadas pela empresa investem entre $1 \%$ e $20 \%$ de seus budgets de marketing em patrocínio. Entre os patrocinadores analisados pela IEG, todos apresentam investimento em ativação de suas marcas em relação a citadas de patrocínio adquiridas, sendo concentrado a cada $\bigcup \$ 1$ investido em patrocínio, $U \$ 1$ é investido em ativação do mesmo.

A emoção do torcedor e a interatividade pode fazer com que meros espectadores se tornem consumidores da marca, assim como em diversos casos de sucesso de marketing esportivo no mundo.

A questão, portanto, que esse trabalho investiga é quais as motivações das empresas para patrocinar times de futebol e eventos esportivos. O objetivo é compreender porque optam pelo patrocínio como estratégia de comunicação das suas marcas e como mensuram o retorno desse investimento. 
O presente estudo busca apresentar, de forma estruturada, a efetividade da realização do marketing de ativação em atividades de patrocínio, para isso será realizada uma pesquisa qualitativa através de um questionário semi-estruturado realizado por meio de entrevista com os gestores de marketing esportivos de agências de marketing esportivo e clubes. 


\section{Referencial Teórico}

2.1. Marcas e Modelos de Avaliação de Marcas

2.1.1 Branding, Marca e sua Importância para as Empresas

O branding - dotar produtos e serviços com o poder de uma marca - é uma atividade antiga e existe como forma de distinguir os produtos de um fabricante dos de outro (INTERBRAND GROUP, 1992). Segundo Kotler (2000), os sinais mais antigos de branding na Europa envolviam artesãos, que eram exigidos pelas associações medievais a colocar marcas em seus produtos para protegerem a si mesmos e aos consumidores contra produtos de qualidade inferior. Nas Belas-Artes, o branding teve início quando os artistas passaram a assinar suas obras.

Antes de definirmos a importância da marca para as empresas, é válido entendermos o conceito da palavra marca em si. Há diversas abordagens relacionadas ao assunto. Abaixo veremos algumas delas.

A marca é "um nome, termo, sinal, símbolo ou design, ou uma combinação de tudo isso, destinado a identificar os produtos ou serviços de um fornecedor ou grupo de fornecedores para diferenciá-los dos de outros concorrentes". (American Marketing Association). Para David Aker (1991), “Uma marca é algo comprado pelo consumidor. O produto pode ser copiado pelo concorrente; a marca é única. O produto pode ficar ultrapassado rapidamente; a marca bem sucedida é eterna", defende Aaker (1991).

De acordo com Kotler (2000), uma "marca é essencialmente uma promessa de a empresa fornecer uma série específica de atributos, benefícios e serviços uniformes aos compradores". As marcas, ainda, ao identificarem a origem do produto e/ou serviço, permitem que o consumidor atribua responsabilidade pelo produto a determinado fabricante ou distribuidor.

Uma marca forte agrega valor tanto ao consumidor quanto à empresa. Ao sinalizar determinado nível de qualidade, a marca fará com que os consumidores se sintam satisfeitos e possam facilmente optar pelo produto em uma compra futura, como enfatiza Erdem (1998). Além de dificultar a entrada de novas empresas no mercado, as quais não possuem marca reconhecida, a fidelidade à marca fornece segurança de receitas futuras e estáveis para a empresa ao proporcionar maior previsibilidade e estabilidade de demanda. Essa fidelidade ainda é responsável por aumentar a disposição a pagar do consumidor, possibilitando a aplicação de preços premium e/ou de margens operacionais elevadas quando comparadas às empresas de marca genérica do mercado. Assim sendo, marcas reconhecidas e consolidadas no mercado resultam em maiores ganhos e lucros para as companhias, gerando maior valor para o acionista e incrementando o valor financeiro das empresas. 


\subsubsection{Os Atributos da Marca (Modelo de Aaker)}

O branding, como vimos anteriormente, está diretamente relacionado ao fato de a marca criar diferenças entre produtos. Essas diferenças, quando positivas, contribuem para a criação de uma marca forte e geram valor tanto para o cliente quanto para a empresa.

Seguindo esse raciocínio, o brand equity é o reflexo do valor da marca como um ativo intangível para uma empresa. Esse conceito implica que os gastos em marketing devem ser considerados como investimentos, pois eles possibilitarão que o consumidor conheça a marca e, posteriormente, realize sua compra.

Há diversos modelos de brand equity que oferecem perspectivas diferentes sobre o assunto. Dentre os modelos mais aceitos pelo mercado, está o Modelo de Aaker, proposto por David Aaker (2007), ex-professor de marketing da Universidade da Califórnia (Berkeley). Segundo ele, o brand equity é um conjunto de categorias de ativos e passivos de marca, os quais aumentam ou diminuem o valor fornecido por um produto ou serviço. Dentre essas categorias estão: (1) fidelidade à marca, (2) conscientização da marca, (3) percepção de qualidade e (4) associações de marca. Cada uma dessas categorias cria valor de formas muito diferentes, as quais serão detalhadas a seguir.

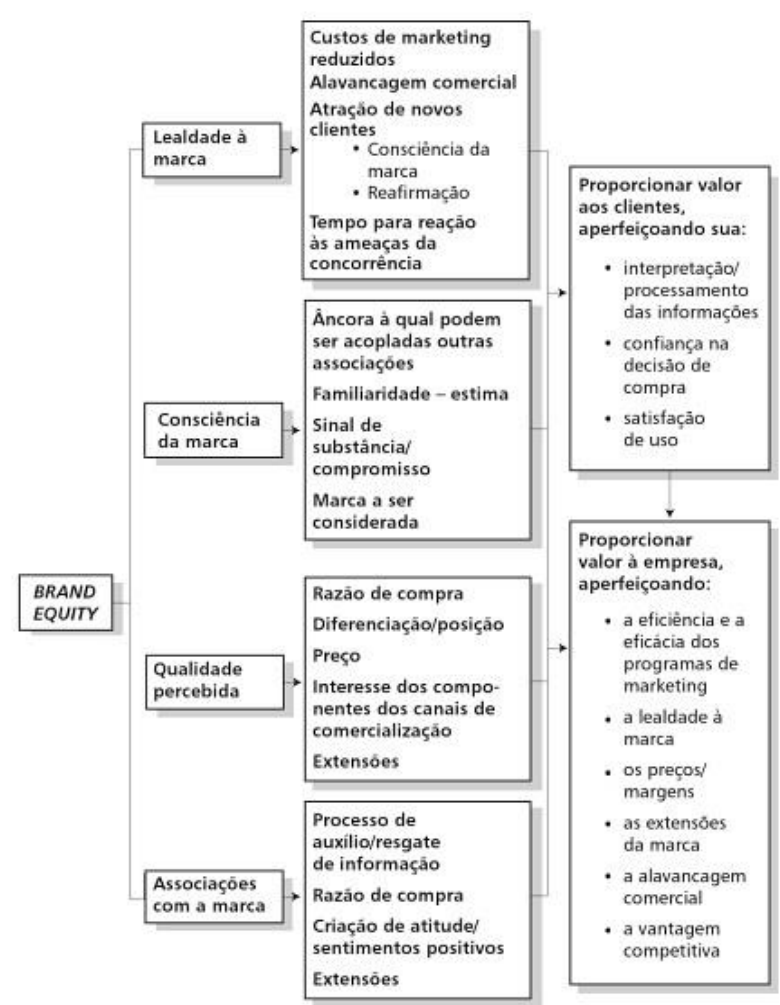

Fonte: Managing Brand Equity: Capitalizing on the Value of a Brand Name de David A. Aaker (1991, pag.23)

Figura 1- Como o Brand Equity gera valor 


\section{Fidelidade à marca}

De acordo com Aaker (1996), consumidores altamente fidelizados à marca podem gerar vendas e fluxos de lucro previsíveis. Além disso, o impacto da lealdade à marca em gastos de marketing é, na maioria das vezes, substancial. Geralmente é mais barato reter clientes do que atrair os novos. Essa lealdade de consumidores existentes representa uma barreira de entrada a competidores, porque o custo de convencer consumidores a modificar sua lealdade é, na maioria das vezes, muito dispendioso. Seguindo esta linha de raciocínio, Ozório (2003) conclui que essa barreira representa um potencial de lucro reduzido ou não atrativo para novos entrantes.

Ainda, Aaker (1996) afirma que "se um concorrente desenvolve um produto superior, seguidores leais darão à empresa o tempo necessário para reagir, dando uma resposta à altura ou neutralizando a ação da concorrência". Em outras palavras, uma marca forte proporciona tempo para reação aos movimentos competitivos.

Além disso, podemos afirmar que uma forma de divulgação da marca e atração de novos clientes é a satisfação dos clientes fiéis. Um cliente satisfeito divulga o sucesso do produto e/ou serviço e indica o seu uso a conhecidos.

Um bom indicador de fidelidade à marca é a disposição dos consumidores a pagar pelos produtos e/ou serviços da marca em questão comparada à disposição a pagar por outra marca que oferece serviços e/ou produtos semelhantes ou com menor quantidade de benefícios. Esse indicador é conhecido como preço premium associado à fidelidade à marca e pode ser positivo ou negativo, alto ou baixo, dependendo das duas marcas envolvidas na comparação.

De acordo com Cuneo (2003), a Apple é um ótimo exemplo de empresa que construiu uma marca forte, significativa para clientes de diversas gerações e países. A empresa alcança altos níveis de fidelidade à marca, em grande parte por cumprir sua missão, definida por "criar ótimos produtos que mudem a vida das pessoas". Segundo a autora, "foram gastos 293 milhões de dólares para criar 73 lojas de varejo e incentivar o frisson em torno de sua marca, incluindo uma loja no SoHo de New York, que atraiu mais de 14 milhões de visitantes em 2003". A lógica por trás disso tudo é de que, quanto mais pessoas puderem ver e tocar os produtos da Apple, mais chances a empresa terá de elevar sua participação no mercado. Outra demonstração do poder da marca Apple e da fidelização de seus clientes ocorre sempre que um novo iPhone é lançado no mercado: compradores e mais compradores formam filas na frente das lojas, tão ansiosos que chegam a virar a noite na porta das lojas para trocar o antigo pelo novo modelo do gadget. 


\section{Conscientização da Marca}

A conscientização da marca refere-se à força da presença de uma marca na mente do consumidor. Aaker (Pág.19, 2009) defende que "se a mente do consumidor estiver cheia de cartazes mentais, cada um ilustrando uma marca isolada, a consciência de uma marca específica se espelhará no tamanho do cartaz que a representa".

Essa conscientização proporciona vantagem competitiva porque esse reconhecimento pode resultar em sensações mais positivas em relação à marca, conferindo a ela um senso de familiaridade, presença e comprometimento junto aos consumidores. Ademais, quanto mais forte for essa concientização, mais a marca será lembrada em um momento chave do processo de compra. Há alguns casos extremos em que o nome da marca se confunde com 0 das próprias categorias de produtos a qual pertence. Esse fenômeno linguístico é denominado metonímia e constitui-se em uma figura de linguagem em que há a substituição, no caso, do produto pela marca, como por exemplo a marca de máscara de cílios Rimmel.

Ainda há o fato de que os compradores, ao recordarem haver visto previamente uma marca, pensam de forma inconsciente que a empresa responsável está investindo grande quantidade de capital em prol de seu reconhecimento e conscientização (Sobrino, 2014). O raciocínio lógico desses consumidores é de que essas empresas não teriam enormes dispêndios de capital com produtos que não acreditam ser realmente bons e, portanto, os consumidores encaram seu reconhecimento como um "sinal" de que a marca é boa.

Aaker (2001) enfatiza que "a consciência de marca é um ativo que pode ser notavelmente durável e, por isso, sustentável. Pode ser muito difícil desbancar uma marca que atingiu um nível de consciência dominante". Ozório (2003) complementa essa análise afirmando que esse fato explica a crescente utilização de estratégias de extensão de linhas de produtos e serviços utilizando, como suporte, marcas consagradas nas últimas décadas. A esperança da empresa é que as opiniões favoráveis dos consumidores sobre a marca sejam transferidas aos novos produtos e serviços. Isso possibilitaria a diluição dos gastos por diversos produtos em diversas unidades de negócio. A Apple, por exemplo, criou diversas linhas do iPod, reprodutor de áudio digital da marca: iPod Shuffle, iPod Nano, iPod Touch e iPod Classic. 


\section{Percepção de Qualidade}

Segundo Aaker (1991), "a qualidade percebida pode ser definida como o conhecimento que o consumidor tem da qualidade geral ou superior de um produto ou serviço pretendido em relação às alternativas".

Adicionalmente, a qualidade percebida afeta diretamente no retorno sobre investimento $(\mathrm{ROI})$ e no retorno das ações. $O$ fato de a qualidade percebida afetar 0 desempenho financeiro da empresa foi comprovado por meio de três estudos:

- Segundo Jacobson e Aaker (1987), estudos utilizando a base de dados PIMS (dados anuais medindo mais de 100 variáveis relativas a mais de 3000 unidades de negócio) mostraram que a qualidade percebida é, por si só, o fator mais importante para o retorno sobre o investimento (ROI) de uma companhia. Essa qualidade percebida contribui para a lucratividade por permitir a prática de preços premium e aumentar o market share da empresa.

- Um estudo realizado durante cinco anos em 1994 com 77 empresas suecas pelo National Quality Center da Universidade de Michigan teve como principal conclusão que a qualidade percebida é fator mais importante da satisfação dos clientes. Essa qualidade percebida, por sua vez, tinha impacto fundamental sobre o ROI. (Eugene Anderson, Claes Fornell e Donald R. Lehmann, 1994)

- "Um estudo realizado durante um período de quatro anos, relativo a 33 empresas de capital aberto, demonstrou que a qualidade percebida teve impacto sobre o retorno acionário" (AAKER e JACOBSON, 1994, Pág.28)

Entretanto, a qualidade percebida pode ser diferente da qualidade atual do produto devido a quatro fatores (AAKER, 2009):

- Consumidores podem ser influenciados por uma imagem prévia de má qualidade. Essa imagem fará com que o cliente não acredite em novas alegações de melhora de qualidade ou, simplesmente, não queira gastar tempo para verificá-las.

- Uma empresa pode obter qualidade em uma dimensão que o consumidor não considera importante. Por não considerar esses quesitos importantes, os compradores não percebem a melhoria na qualidade ou não obtêm nenhum benefício relacionado a essa melhoria.

- Os compradores tendem a se apegar a uma ou duas características de um produto ou serviço que associam à qualidade. Isso porque eles raramente detêm todas as informações necessárias para fazer uma escolha racional e objetiva relacionada à qualidade. 
- Os consumidores podem procurar características erradas ao buscar qualidade simplesmente porque eles não sabem julgar ao certo os atributos que fazem com que o produto e/ou serviço tenha boa qualidade.

Desse modo, vale destacar que é importante ouvir o consumidor e entender suas necessidades para que o dispêndio de capital relacionado à melhora da qualidade do produto e/ou serviço não seja em vão.

Podemos concluir, portanto, qua a qualidade percebida é capaz de gerar valor de diversas formas, dentre elas: pela percepção positiva em relação à marca, que pode permitir a efetuação de extensões de marca; pela possibilidade de praticar preços premium devido à maior disposição do consumidor a pagar por um produto com alta qualidade percebida; pela inclusão e consideração da marca pelo consumidor nas alternativas de compra etc.

Um exemplo dessa qualidade percebida ocorre com a linha de computadores Mac, da Apple, que é amplamente conhecida por ter um sistema operacional seguro e com baixo índice de suscetibilidade a "vírus". Essa característica do computador é considerada, por muitos usuários, sinônimo de qualidade e é fundamental durante a decisão de compra. Nesse sentido, um Mac teria maior qualidade percebida pelo consumidor do que um computador com sistema Windows, mais suscetível a "vírus".

\section{Associações de Marca}

As associações de marca estão diretamente relacionadas àquilo que a organização deseja que a marca represente na mente de cada consumidor. Marcas fortes e consolidades são capazes de gerar percepções que vão além dos atributos funcionais dos produtos e criam diferenciações a partir das associações à marca.

A Apple, por exemplo, utiliza-se do símbolo da maçã mordida como ingredientechave no reconhecimento da marca.

Além disso, o sucesso de extensões de marca está diretamente ligado a associações positivas relacionadas à marca-mãe, pois existe uma percepção de comparabilidade entre ela e o produto de extensão.

Vale lembrar que muitos consumidores estavam ansiosos para o lançamento do iPad, dispositivo em formato tablet da Apple, em 2010. Apesar de não ter muito conhecimento sobre o aparelho, muitos usuários da marca inferiram que ele teria a mesma qualidade e seria tão bom quanto os outros produtos Apple e, por esse motivo, não hesitaram na hora de comprá-lo. 
Segundo a etimologia da palavra latina, patrocínio refere-se à proteção e amparo. As ações de patrocínio tiveram origem no auxílio financeiro de instituições com o intuito de amparar atividades realizadas por esta. No entanto, o conceito atualizado encontra-se mais amplo, sendo definido pelos benefícios adquiridos pela atividade para a instituição e/ou empresa.

Para Meenaghan (1991), patrocínio é um investimento em uma atividade que tem como contrapartida o acesso a um potencial de exploração comercial diretamente relacionado a essa atividade. Contudo, tal definição, apesar de clara, vem sofrendo modificações a respeito das mudanças em suas funções e atividades. Segundo D'Astous (1995), existem dois tipos de natureza de patrocínio, podendo ser comercial ou filantrópico: no primeiro o patrocinador visa obter benefícios mercadológicos, já no segundo o patrocinador é mais proeminente ao suportar uma causa sócio-cultural.

Javagli (1994) define patrocínio como a assinatura e/ou subscrição de um evento especial, com o intuito de apoiar objetivos corporativos, através de um aumento da atividade corporativa e do reconhecimento da marca ou, então, diretamente estimulando vendas de produtos e serviços. Para D’Astous (1995), patrocínio é um elemento do conjunto de atividades de comunicação, no qual a empresa concede suporte financeiro a uma entidade, podendo esta ser individual, uma organização ou um grupo, a fim de viabilizar que esta atividade desenvolva suas atividades e obtenha benefícios desta associação em termos de reconhecimento por parte do consumidor e da imagem global propagada.

A fim de relacionar atividades de marketing a ações de patrocínio, Bennett (1999) afirma que patrocínio é uma ferramenta importante de comunicação de marketing, visto que busca adquirir publicidade favorável para a empresa e/ou suas marcas dentro de um público-alvo determinado, através do apoio a uma atividade não diretamente ligada ao negócio da empresa.

Cornwell e Maignan (1998) explicam a existência de um determinado valor para projetos de patrocínio, denominado fee, no qual o pagador obtém direitos de associar com o evento e divulgar esta associação. 


\subsubsection{Objetivo das empresas patrocinadoras}

Empresas podem apresentar muitos objetivos relacionados a atividades de patrocínio e entendê-los é fundamental a fim de escolher um projeto adequado.

Crowley e Meenaghan (1991) denotam a existência de alguns interesses relacionados à imagem da empresa por parte dos patrocinadores, como aumentar o conhecimento da marca, lançar uma nova marca, reforçar ou mudá-la. Na mesma linha de raciocínio, Jawalgi (1994) revela que, além das motivações individuais dos gerentes, dois outros objetivos destacam-se caracterizando a maioria das atividades de patrocínio: aumento da imagem corporativa e aumento da imagem da marca.

Harvey (2006) explica como é percebida uma empresa que utiliza o patrocínio como ferramenta de comunicação com objetivos relacionados à imagem. Para isso utilizase o conceito do efeito auréola, o qual considera que investir em um projeto de patrocínio faz com que as empresas sejam positivamente reconhecidas ao indicar que, de alguma forma estão ajudando um evento a ser realizado, um time a disputar uma competição, uma personalidade ter alta performance, e influenciando, portanto, a intenção de compra como um sinal de gratidão pelo patrocinador.

Dentre os objetivos possíveis, o retorno imediato em venda de produtos vem se tornando cada vez mais comum, visto que a empresa define sua participação em determinados eventos baseado na possibilidade de receita imediata. No entanto, é extremamente difícil determinar que o aumento das vendas é proveniente de uma ação de patrocínio, sendo geralmente o resultado de um conjunto de fatores. Como afirma Farrely e Quester (1998), vendas poderiam ser explicadas por uma variedade de fatores que, integradamente, propiciam mudanças no volume de vendas, impossibilitando a atribuição conclusiva a um único fator.

Crompton (2004) cita a existência de mais objetivos de empresas em patrocinar uma entidade, tais como aumento do reconhecimento da marca, demonstração de novos produtos, melhora do moral dos empregados e da imagem da empresa. Para Fahy, Farrely e Quester (2004), acordos de patrocínio buscam demonstrar posicionamento, uma vez que encontra-se diretamente relacionado à imagem da prioridade a ser patrocinada.

A fim de constatar tais afirmações, a empresa americana IEG realizou uma pesquisa com 110 empresas, com o intuito de classificar os objetivos procurados pelos patrocinadores em patrocinar um projeto, obtendo um resultado expressivo na preocupação com o reconhecimento da marca e estreitamento do relacionamento dos funcionários com os clientes da marca. 


\subsubsection{Ativação de Patrocínio}

Um ponto importante no estudo das atividades de patrocínio é a sua ativação. Ativar um patrocínio significa desenvolver atividades de comunicação e promocionais, utilizando os direitos adquiridos em um projeto de patrocínio. Segundo Nardone (2007), atividades de ativação buscam trazer vida ao patrocínio.

Cornwell e Maignam (1998) constatam que a utilização exclusiva de ferramentas de patrocínio não otimiza seu potencial, sendo mais efetivo quando ativado juntamente a outras formas de comunicação, podendo funcionar como uma forma de otimizar investimentos, uma vez que proporciona um melhor aproveitamento das atividades patrocinadas.

Nardone(2007) afirma que a ativação de patrocínio pode custar até 3 vezes o valor do direito adquirido para patrocinar o evento, visto que estratégias de ativação devem ser utilizadas juntamente com outras atividades promocionais. No entanto, como os projetos existentes já possuem propriedades e direitos que dão visibilidade ao patrocinador, o que leva as empresas a se despreocupar em investir recursos extras para promover uma maior exposição.

Estudos realizados por Grohs, Reinhard e Vsetecka (2004) apresentaram como resultado que uma maior ativação de patrocínio resulta em um aumento da transferência de imagem do evento patrocinado para o patrocinador, afirmando a necessidade de empresas produtoras buscarem uma maior otimização de projetos através da prestação de serviços complementares que auxiliem na ativação.

Poon e Prendergast (2006) explicam que, quanto maior a expertise do patrocinador em auxiliar a organização de um evento, mais ele se sente envolvido e responsável pelo evento, atuando não somente como financiador, mas também como promotor.

Segundo Nardone (2007), profissionais de marketing possuem o desafio de realizar seu trabalho de forma a maximizar o retorno do investimento no processo de construção da marca. Portanto, o profissional envolvido na atividade de ativação deve conhecer a fundo os objetivos da empresa e a estrutura financeira, uma vez que a empresa precisa dispor de recursos suficientes para atividades de ativação, de maneira a avaliar a viabilidade de execução de determinado projeto e uma melhor otimização do retorno sobre o investimento realizado.

Pode-se concluir, portanto, que a ativação do patrocínio consiste em atividades de comunicação e promocionais desenvolvidas por patrocinadores, utilizando os direitos adquiridos através da compra de patrocínio, buscando intensificar e melhorar a eficiência de 
um projeto patrocinado. No entanto, alguns patrocinadores são mais engajados em projetos que os demais, utilizando a expertise obtida para melhorar a ativação do patrocínio, visto que o investimento a ser feito no processo de ativação é alto, necessitando um planejamento de recursos financeiros mais acurados por parte das empresas patrocinadoras.

\subsubsection{Relação da lembrança da marca com a medição de patrocínio}

A lembrança da marca é também um conceito muito explorado na medição de patrocínio. No entanto esse conceito é menos utilizado que o de equivalência de mídia, uma vez que é mais custoso e demorado de se realizar, visto que necessita a condução de um processo de pesquisa.

Um fator que certamente poderia auxiliar a medição da eficácia de um projeto de patrocínio seria o aumento da recordação da marca da antiga empresa patrocinadora. Assim uma nova empresa patrocinadora poderia usar esses dados para tomar decisões em uma avaliação, possuindo maior valor os projetos que possuem maior lembrança. Contudo, Ghros, Reinhard e Vsetecka (2004) afirmam não ser possível assegurar que uma melhora na imagem ou aumento da lembrança da marca seja resultado de um determinado projeto de patrocínio, uma vez que outras atividades podem também influenciar o recall da marca.

Com base nisso, Cornewll e Meignan (1998) desenvolveram métodos de mensuração dos efeitos do patrocínio com base na exposição e em estudos tracking, que buscam medir a lembrança da marca, familiaridade, qualidade e preferência por esta.

Ghros, Reinhard e Vsetecka (2004) propõem atividades que melhorem o recall da marca em um projeto de patrocínio, visto que apenas o volume de exposição de uma marca em um evento não faz com que o recall seja alto, necessitando, portanto, que haja um relacionamento da marca com momentos positivos com o público participante do evento.

No entanto, Crompton (2004) contraria esse conceito ao afirmar que a utilização do recall é um parâmetro defeituoso. Visto que há uma maior probabilidade de as pessoas associarem um determinado patrocinador a um evento baseado na popularidade de uma marca do que através da representatividade da logomarca vista em um determinado evento de uma empresa. 


\subsubsection{Retorno do investimento em patrocínio e na marca}

A primeira pergunta que se faz ao iniciar o assunto é: por que investir no esporte? Qual o benefício obtido pelas empresas ao investir no esporte?

Atualmente, com os mercados globalizados e altamente competitivos, repletos de produtos similares, não basta desenvolver estratégias como habitualmente vinha se desenvolvendo, utilizando publicidade, propaganda, relações públicas, merchandising, venda pessoal e promoção de vendas para conquistar o mercado alvo. É preciso obter um diferencial competitivo. Neste ponto, o esporte tornou-se ponto chave na relação da empresa com o mercado. Investir no esporte é proporcionar à empresa uma relação mais próxima com o consumidor do seu produto, pois, ao obter esta proximidade e empatia da marca com o consumidor, fidelizar o mesmo torna-se mais fácil.

Antes da década de 80 , as empresas investiam no esporte porque os diretores eram aficionados nesta atividade; não esperavam um retorno, mas apenas ofereciam uma ajuda de custo, ao qual denominamos mecenato. O mecenato acabou, não se espera nos dias de hoje que esta boa vontade ocorra. O interesse econômico permeia a relação do esporte com as empresas, pois o esporte é um negócio lucrativo, e como tal deve ser encarado pelas empresas que nele investem.

Os benefícios do patrocínio à marca da empresa são marcantes. Pozzi (1998, p.109) afirma: Em uma sociedade cada vez mais competitiva, desenvolver a imagem frente ao público constituiu um fator de sobrevivência para as empresas. Aí entra o patrocínio esportivo, considerado um meio para obter resultados em termos de marca, conhecimento do público e imagem empresarial.

Como salienta Melo Neto (2000, p.25), no patrocínio esportivo, a empresa objetiva potencializar a sua marca. As maiores motivações para o investimento no esporte são o seu forte apelo junto à mídia, o vasto mercado constituído pelos torcedores, praticantes e admiradores das diversas modalidades esportivas e a sua segmentação. $O$ benefício principal é a divulgação e, em menor escala, a valorização da marca, que ganha novos atributos advindos do esporte. Os maiores retornos são os de mídia, o institucional e o de vendas. Através do patrocínio a marca do patrocinador se torna forte, vibrante e consagrada. Ganha espaço na mídia e torna-se conhecida do grande público. No patrocínio, a marca vem sempre associada a algo: um evento, um clube, um atleta, um artista, uma equipe ou até mesmo um acontecimento. É por meio desta associação que ocorre o processo de agregação de valor à marca. A marca recebe algo, sob a forma de atributo, que originalmente não possui. Eventos de sucesso e patrocínios de sucesso são os agentes formadores de tais atributos. Quando o evento patrocinado pela marca se constitui num 
verdadeiro sucesso, a associação é direta e imediata: um evento de sucesso, uma marca de sucesso, um patrocínio de sucesso. Tais atributos conferem à marca do patrocinador uma personalidade forte, uma imagem altamente positiva, o que é uma garantia de lembrança na mente do consumidor (recall).

Assim como qualquer outro negócio, o esporte e mais especificamente o marketing esportivo deve ser compreendido como uma atividade comercial altamente rentável se realizada de forma planejada e estruturada.

A empresa deverá investir em estratégias que façam sua marca mais visível ao seu público- alvo, que atinjam um grau de credibilidade capaz de motivar este consumidor no momento de aquisição do produto. Porém, além da compra, é necessário que o consumidor mantenha a fidelidade ao produto, que é baseada na credibilidade adquirida com a associação ao esporte.

Mesmo sabendo da importância do patrocínio esportivo, são poucas as empresas que quantificam o retorno sobre este investimento. O resultado de uma pesquisa realizada pela Performance Research revelou que $72 \%$ das empresas não têm orçamento para pesquisar esse retorno, apenas $1 \%$ faz pesquisa neste sentido e $61 \%$ não recebem essas informações (KEARNEY, 2003).

Porém, este panorama tende a mudar no momento que os patrocinadores buscam obter informações a respeito do quanto ganham ou deixam de ganhar investindo no esporte pela mídia espontânea - mídia gerada por notícias, notas, reportagens e transmissões sem custo para a empresa -ou com o possível aumento das vendas. Grandes empresas estão na busca de formas mais confiáveis e eficazes de avaliação do retorno do patrocínio esportivo. Cada vez mais é maior a consciência sobre a importância destas avaliações pelas empresas patrocinadoras.

Antonio Afif (2000), em "A Bola da Vez", frisa que o Retorno do Investimento é proporcional à visibilidade que sua marca obtém na mídia de forma espontânea, isso quando seu objetivo é projetar a marca no mercado. Quando o objetivo é o aumento das vendas a mensuração é mais difícil. Essa análise deve ser feita comparando as vendas do produto antes e depois do patrocínio. Porém, destaca o autor, se a marca do fabricante já for conhecida, esse cálculo é mais difícil de ser feito pois não haverá condições de saber, com precisão, quanto a campanha contribuiu efetivamente para o aumento das vendas.

Brunoro (1997) constata que hoje as empresas começam a compreender que, além do patrocínio esportivo, podem ter a oportunidade de realizar alguns negócios participando da compra e venda de jogadores em parceria com o clube, e ainda licenciar a marca do time para utilizá-la em ações de marketing. É importante que as companhias que queiram investir no esporte estejam cientes de que o nome do time que estão patrocinando deve ser preservado de todas as maneiras. Muitas empresas, na ânsia de buscar retorno 
rápido no seu investimento, acham que devem divulgar mais as suas marcas que o nome do próprio clube.

O importante em relação à prática do marketing esportivo é saber que ele proporciona benefícios a curto, médio e longo prazo e que o poder de percepção do cliente consumidor é cada vez maior em relação a isso. Por exemplo, aumento do reconhecimento público: em função do momento, os torcedores tornam-se mais suscetíveis ao apelo promocional; rejuvenescimento da imagem da empresa: o exemplo maior disso é com o Banco do Brasil e sua campanha por novos clientes (jovens), exposição constante da marca na imprensa e em todas as mídias - exemplo: o outdoor que fica atrás dos atletas durante a entrevista (backdrop), reforço da imagem corporativa - em função do investimento no setor esportivo a empresa passa a ser vista de maneira diferenciada pelo consumidor: simpatia junto ao público e mídia - a comunicação que envolve consumidor e imprensa ganha um papel de cumplicidade, envolvimento da empresa com a comunidade. Atualmente é possível afirmar que os clubes e entidades esportivas trabalham com dois conceitos importantes, o patrocínio e a marca.

Clubes e entidades esportivas têm dois tipos de produtos para serem comercializados: o patrocínio e a marca. A CBF obtém grandes lucros na venda do patrocínio dos seus atletas, equipes, competições e com a comercialização de suas marcas, através de contratos de licenciamento e franquia. (MELO NETO, 2007).

As grandes equipes de futebol faturam com a venda de camisetas e produtos relacionados à sua marca. Quem ganha com esse sucesso de vendas são as próprias equipes e a CBF que dão total apoio a essa forma de divulgação. Fica fácil vender seus produtos por terem uma marca muito forte e essa recompensa nas vendas, faz com que as equipes se tornem cada vez mais competitivas. As empresas vêm cada vez utilizando estratégias de marketing no meio esportivo, principalmente através do fornecimento de material esportivo, onde divulgam sua marca e assim tornam-se mais competitivos no mercado. 


\subsubsection{Conceito}

Segundo Marcos Vinicius Freire (2008, p. 21) em "A história do marketing dos aros", a história do marketing esportivo nos remete a um período distante de uma civilização que é o berço de toda a base da cultura contemporânea - a civilização grega, a mais importante e influente de toda antiguidade. O pensamento grego e seus mitos tiveram grande influência na formação do nascimento dos esportes. Foi na grandiosidade da história dos jogos da antiguidade grega que o Barão de Coubertin iniciou o que viria a ser o maior evento da Terra, os Jogos Olímpicos. Desde os festivais da antiguidade, a atividade comercial já era o centro das atenções. Comerciantes, vendedores de comida e artesãos tinham entrada garantida nos jogos, os poetas eram contratados para celebrar a vitória dos atletas e os escultores para eternizar a imagem dos vitoriosos. Além disso, eram emitidas moedas para comemorar as vitórias nas competições hípicas.

Segundo Freire, os cidadãos vitoriosos de Olímpia eram patrocinados com a alimentação pelo resto de suas vidas. Governadores e reis frequentemente cunhavam moedas para homenagear os atletas e foi também nessa época que surgiu a idéia de medalhas e da numismática comemorativa.

Em um contexto moderno, os Jogos Olímpicos se transformaram em um grande negócio, que envolve planejamento estratégico e uma visão comercial e de marketing definidas.

A inevitável transformação do esporte, graças aos jogos olímpicos, ajudou a criar a necessidade de profissionais especializados nas áreas de marketing esportivo, carreira em evidência nos dias de hoje (FREIRE, M.V, 2008).

Em "Minha vida e minha obra" (1926), mesmo sem explicitar definições conceituais, Henry Ford mostra ter sido adepto e, pode-se dizer, um dos pioneiros na busca de resultados de marketing através da aplicação do esporte como ferramenta. Em seu texto, após uma série de menções à utilidade de atividades esportivas na promoção de produtos, o referido autor descreve o modo como tornou conhecido o modelo $\mathrm{T}$, seu primeiro carro de estrada para todos os fins, afirmando: "-a propaganda mais eficaz era vencer uma corrida ou estabelecer um recorde" (Ford, 1926, p. 56).

Relatos como este demonstram que a interação de elementos esportivos com o composto promocional das organizações é um valioso instrumento, há muito percebido e utilizado em termos de persuasão e promoção (Teitelbaum, Ilton. 1997) 
Bourg e Gouguet (2005) colocam o processo de mundialização do esporte como constituído por três períodos.

O primeiro (1850 a 1914) tem como características a apropriação dos jogos da Idade Média, pela sociedade inglesa do período da Revolução Industrial, com valores voltados à competição e à concorrência. No segundo período, entre guerras aos anos 1970, tem-se a incidência da remuneração nos esportes e a propagação de transmissões esportivas via rádio, reforçando sua dinâmica mercantil. No terceiro período, a partir dos anos 1980 , os objetivos do esporte de alto rendimento se voltam para as características mercantis: comercialização, cientificismo, lucro e midiatização, tornando os eventos de proporções planetárias. Por essa proporção internacional, o confronto entre os melhores supera as distâncias geográficas e exige uma indústria que atenda a essa demanda e promova tais confrontos: estruturas esportivas, empresariais, midiáticas e financeiras (ALMEIDA, B.S, NUNES, R.J.S \& VASTUIN, J. 2008)

Sem poder especificar precisamente seu início, o fenômeno esportivo atual é aceito como em processo, nomeado como modernização ou profissionalização, descrito por alguns autores como uma etapa passada por modalidades inicialmente amadoras e a caminho de uma globalização ou espetacularização, mais evidenciadas nos casos do futebol e voleibol brasileiros (AFONSO, 2004; MARCHI JR, 2004; PRONI, 1998). Estes casos específicos serão analisados mais à frente.

O Marketing Esportivo é um novo segmento do marketing aplicado ao segmento de esportes no qual se destaca o marketing promocional e como tal envolve uma série de atividades que compõem o tradicional mix de marketing, ou seja: produto, preço, promoção, ponto de venda, avaliação constante do mercado e suas variáveis políticas, econômicas e ambientais, seleção de eventos, atletas, equipes, calendários esportivos, contratos de endorsement (testemunhal de atletas), compra de espaços de mídia em eventos esportivos, atuando, portanto, em toda dimensão institucional de uma marca ou empresa.

O marketing esportivo pode ser observado também como uma forma de merchandising, uma vez que cada modalidade esportiva possui particularidades que permitem a utilização de diferentes estratégias, tais quais o local de competição, uniformes utilizados por atletas, o posicionamento dos equipamentos, o local destinado ao público e os demais personagens que participam do evento esportivo. Assim, o produto não aparece para o consumidor de maneira apelativa, mas compondo o ambiente sem roubar a cena principal que é o evento esportivo.

O marketing esportivo pode ser entendido com um tipo de mídia alternativa composta para maximizar a exposição de uma marca e/ou produto, visto que a empresa investidora de marketing esportivo deverá realizar, também, ações de publicidade a fim de explicar os produtos comercializados pela marca. 
O esporte atualmente é encarado como negócio, uma vez que a indústria esportiva mundial movimenta, anualmente, bilhões de dólares, e apresenta mais de 140 modalidades esportivas sendo praticadas em todo o mundo, o que amplia ainda mais as oportunidades de exploração da imagem e do prestígio dos atletas.

Atualmente, um assunto muito em voga no mercado esportivo é dos bons resultados obtidos através do marketing esportivo, das estratégias de promoção de atletas, marcas, times e eventos, que por sua vez impulsionam vendas de produtos licenciados e ingressos e aumentam as cotas de patrocínio e televisão. Segundo a Revista IstoÉ Dinheiro, edição de 4 de agosto de 2004, as olimpíadas de Atenas movimentaram US\$12 Bilhões em infraestrutura e marketing do evento, e de acordo com a empresa de marketing esportivo Top Sport, em 2003, o patrocínio de competições no mundo movimentou um montante de US\$26 Bilhões, sendo R\$585 milhões apenas no mercado Brasileiro (SOUZA, C.A.G. 2004).

\subsubsection{Objetivos do Marketing Esportivo}

Diante desse cenário, o marketing esportivo vem crescendo cada vez mais e ganhando maior importância no âmbito comercial, devido a possibilidade de avaliar o mercado, os concorrentes e consumidores, desenvolver estratégias e táticas promocionais, fortalecer a marca e a imagem da empresa e/ou produtos, planejar o uso da mídia para obter retorno espontâneo, Abrir e conquistar novos mercados, usar a comunicação como ferramenta estratégica. No entanto, tal cenário apresenta desafios, como: o incremento de novas e diferentes atividades esportivas, aumento do tempo de lazer e do tempo de vida da população, o aumento no número de revistas esportivas e revistas especializadas, o aumento da exposição da mídia de massa, o aumento no número e tipos de instalações, eventos e participação, a expansão dos bens e serviços relacionados ao esporte e o aumento no número de atividades esportivas em nível profissional;

O Marketing esportivo atua não somente em clubes ou organizações esportivas mas também como parte de uma estratégia de empresas e organizações locadas fora do setor esportivo, podendo, assim, diferenciar em dois eixos de atuação: O Marketing do esporte e o marketing através do esporte.

Segundo Mullin, Hardy e Sutton (2000) destacam a existência de dois eixos em sua definição de marketing esportivo:

O Marketing esportivo consiste em designar todas as atividades relacionadas a satisfazer as necessidades e desejos dos consumidores esportivos através de processos de troca. Com base nesse conceito, Contursi (1996) desenvolveu dois eixos principais: O 
marketing de produtos e serviços diretamente ligados para os consumidores esportivos (por exemplo: Academias, clubes, futebol, corridas e o marketing de outros produtos e serviços através da utilização das promoções esportivas (ex: Cigarros, automóveis e vitaminas)

No entanto, temos que considerar a visão de Yanaze (2000, p.88) na qual não existem versões de marketing e sim ações de marketing sendo empregadas em diferentes áreas e setores.

Enfim, o Marketing esportivo é, sem dúvida, uma das mais promissoras áreas deste segmento que, com certeza, ainda tem muito a ser explorado e estudado, de forma que, a longo prazo, venha a ser planejado estrategicamente e realizado com os menores riscos afim de evitar crises.

\subsubsection{Marketing esportivo no Brasil}

A sociedade brasileira em geral tem se manifestado nas mais diferentes esferas - no meio acadêmico, através da mídia, entre outras - sobre a necessidade urgente de se profissionalizar o esporte, de se administrar o esporte com transparência: o caminho para o país obter sucesso a nível olímpico seria o aperfeiçoamento da administração esportiva do país, a sinergia entre trabalho em equipe, liderança e planejamento. É necessário, antes de tudo, que se conheça o esporte no Brasil, que se tenha a real avaliação da realidade nacional em termos das condições e necessidades existentes, que sejam desenvolvidos estudos e pesquisas na área.

Diagnóstico realizado em 1971 sobre Educação Física e Esporte no Brasil (Costa, 1971) já apontava a evolução da indústria do esporte em relação aos segmentos de materiais esportivos, de construções e instalações destinadas a Educação Física, Esportes e Recreação, sem, no entanto, se referir a questões de gestão, administração e marketing esportivo.

A partir deste momento e até os dias de hoje, diferentes universidades, faculdades, entidades profissionais, sindicatos passaram a oferecer de maneira significativamente crescente a disciplina Administração Esportiva e cursos de administração esportiva de extensão universitária, de especialização, de curta duração - para públicos das áreas de educação física e esporte e não profissionais que atuam em organizações esportivas. Como consequência da participação nos cursos oferecidos, a partir de 1970, começaram a ser produzidas monografias, dissertações e teses de doutorado ligadas ao tema, também em cursos de Administração, Marketing, Engenharia.

Recentes levantamentos foram realizados por Moraes et al.(1999), que analisaram os artigos publicados na Revista Paulista de Educação Física, entre 1986 e 
1997, e verificaram que, dos 155 artigos publicados entre 1986 e 1988, 5\% eram relativos à área administrativa e, entre 1992 e 1997, 1\%; e Paulo et.al. (1999) que realizaram levantamento das 173 dissertações de mestrado outorgadas no Curso de Mestrado da Escola de Educação Física e Esporte da Universidade de São Paulo, e encontraram seis trabalhos na área de Administração Esportiva.

A àrea de Marketing Esportivo teve grande impulso com publicações recentes, como reflexo da nova visão dada pela legislação do país, o que incentivou a entrada de empresas investidoras nos clubes e entidades de administração do esporte e introduzindo os principais conceitos e diferentes abordagens da área (Melo Neto, 1995; Contursi, 1996; Melo Neto, 1997; Melo Neto, 1998a; Pozzi, 1998; Cardia, 2004).

Refletindo o reconhecimento do Governo Federal em relação ao tema, destacase a publicação do Anual do Seminário INDESP de Marketing Esportivo (1995) promovido pelo INDESP - Instituto Nacional de Desenvolvimento do Desporto, em 1995, marco da área, com textos conclusivos das palestras proferidas por profissionais de diferentes segmentos do esporte nacional e de outros países. (Melo Neto, 1995; Contursi, 1996; Melo Neto, 1997; Melo Neto, 1998a; Pozzi, 1998; Cardia, 2004).

Para Macedo (1999) associar marcas e serviços ao esporte tornou-se um instrumento de comunicação frequente no planejamento de marketing das empresas brasileiras na década de 1990, porém segundo Brunoro (1997), o patrocínio de equipes no Brasil é fato recente, já que esta prática teve início a partir dos anos oitenta, quando os clubes começaram a divulgar o nome de empresas em suas camisas. Até aquele momento, o patrocínio ainda encontrava muita resistência por parte das agremiações e dos torcedores.

Enfim, é notável o crescimento dos estudos e aperfeiçoamento em Marketing no Brasil. Um país considerado melhor do mundo em um esporte que movimenta bilhões em investimentos de marketing, o futebol, deve estar preparado para utilizar isso a seu favor, como forma de crescimento da nação. 


\subsubsection{Marketing de clubes, Patrocínio, Licenciamento e promoção de vendas}

Existem diversas possibilidades de negócios dentro da indústria do esporte que, segundo Pitts e Stotlar (2002), é o mercado no qual os produtos oferecidos aos compradores relacionam-se ao esporte, fitness, recreação ou lazer e podem incluir atividades, bens, serviços, pessoas, lugares ou idéias.

Algumas dessas formas de utilização do marketing esportivo dentro do universo complexo da indústria do esporte englobam atividades como: patrocínios, eventos, licenciamentos e franquias, material esportivo e promoção de vendas.

O patrocínio, assunto central desse estudo, abrange basicamente o apoio contratual e pecuniário de organizações a atores do esporte, equipes ou atletas individuais, a ligação do nome de uma empresa a um evento já consagrado ou a veiculação de mensagens comerciais vinculadas a coberturas jornalísticas de acontecimentos pertencentes à esfera esportiva (TEITELBAUM, 1997).

Podemos citar, como ilustração tradicional, patrocínio de camisas dos principais clubes de futebol de todo o mundo, o investimento de grandes empresas na realização de uma copa do mundo utilizando o logotipo do evento em suas mensagens comerciais ou das respectivas logomarcas nos locais dos jogos ou ainda a presença das logomarcas em carros e uniformes de pilotos de Formula 1, assim como inserção de marcas nas transmissões.

Para Melo Neto (1998), o marketing de clubes é uma modalidade de marketing que tem como objetivo buscar receitas alternativas através de ações direcionadas para segmentos que promovam ações como a realização de promoções durante a transmissão dos jogos do clube; comercialização da marca do clube como grife; venda de franquia das escolinhas; gestão de empreendimento do tipo parcerias na construção de shopping centers, outlets; venda da publicidade em seu estádio; venda de patrocínio do clube e/ou de suas equipes; venda de serviços para seus associados e torcedores; venda de títulos de sócios; contratos de arrendamento, leasing e concessão com fornecedores e prestadores de serviço e, venda de jogadores.

A partir dos exemplos citados, concretiza-se a idéia de que, em marketing esportivo, sob uma ótica integrada de mercado, a viabilidade de se obterem bons resultados está em proceder múltiplas intersecções do esporte com os interesses empresariais. Assim, a relação entre o marketing e o esporte prevê iniciativas não usuais como as descritas por Campomar (1992), porém tal relação deve se dar de forma interativa e juntamente aos de diversos agentes econômicos. 
Segundo Melo Neto (1998), as opções de uma empresa patrocinadora que deseja investir num evento são: venda do patrocínio ou co-patrocínio; venda do direito do uso da marca do evento; venda do licenciamento; venda de estandes; permissão para a instalação de postos de serviços; venda de publicidade no local do evento; negociação de apoio de empresas em troca de prestação gratuita de serviços e negociação com as empresas prestadoras de serviços de instalação de som, montadoras de palcos e arquibancadas e de transporte logístico utilizado na promoção de eventos.

Em se tratando de licenciamentos e franquias, Kotler (1996), explica que eles compreendem um acordo entre duas partes para que um licenciado possa usar o processo de fabricação, a marca, a patente, o segredo comercial ou outro item de valor que pertença a um licenciado, mediante o pagamento de uma taxa ou de royalties. A organização de uma franquia constitui uma associação contratual entre um franqueador e um franqueado, baseada, normalmente, em um único produto, serviço ou método de operação, marca registrada ou patente desenvolvida pelo primeiro.

No que concerne ao material esportivo, Melo Neto (1995), diz que este material se restringe às negociações que aproximam os atletas do esporte aos fabricantes de produtos voltados à prática do esporte em si. Os fabricantes não apenas equipam os atletas para o desempenho de suas atividades, como também utilizam a sua imagem para promover suas próprias marcas e produtos.

E, por fim, Pitts e Stotlar (2002), afirmam que a promoção de vendas engloba todos os meios de comunicação que não se encaixam nas categorias de propagandas, venda pessoal ou publicidade. São atividades de curta duração destinadas a levar os consumidores a uma troca imediata. Ela envolve, ainda, a pesquisa, o estudo, a afinação e a aplicação de todas as idéias e iniciativas que possam conduzir à coordenação, ao melhoramento e ao desenvolvimento das vendas.

Pozzi (1998) destaca que depois que o esporte é escolhido, o patrocinador deve verificar as condições gerais, o grau de profissionalização na gestão administrativa e o histórico do clube. 


\subsubsection{Marketing no Futebol}

O futebol se tornou, ao longo dos anos, um dos maiores esportes praticados em todo o mundo. Os eventos realizados em diversos países envolvem grandes patrocinadores e um público de milhões de pessoas. Além disso, a prática amadora também não tem fronteiras e qualquer espaço é uma alternativa para uma boa pelada.

No Brasil e em países europeus o segmento esportivo, especialmente o futebol, movimenta bilhões de dólares. Segundo números colhidos pela FGV em 2002 e apresentados no Fórum internacional - O Grande Negócio do Esporte, ocorrido em 2003, no Rio de Janeiro, a indústria do esporte movimenta $\mathrm{R} \$ 42$ bilhões de PIB total; $\mathrm{R} \$ 8,7$ bilhões de PIB dos serviços ligados ao esporte; $R \$ 12,5$ bilhões de PIB da industria de artigos esportivos; e $\mathrm{R} \$ 450$ milhões em entradas em eventos esportivos (SOUZA, C.A.G, 2004).

Exemplos disto são as frequentes transações financeiras que movimentam um volume expressivo de recursos: a negociação de jogadores, a venda de material esportivo, a publicidade e das escolinhas franqueadas (PEREIRA, 2003).

O esporte passou a ser uma das atividades mais lucrativas do setor de negócios. Segundo especialistas, o esporte movimenta, hoje, no Brasil, cerca de US\$ 2 bilhões por ano e tem uma perspectiva de crescimento de $2 \%$ ao ano nos próximos quinze anos.

No entanto, o futebol não seria o mesmo se não houvesse a inserção do marketing esportivo dentro do seu contexto. Como constata Santos (1998), a crescente popularização e a consequente insustentabilidade do amadorismo no futebol fez com que a CBD, mesmo com certa relutância, adotasse o profissionalismo já nos idos da década de 1930. Mas o profissionalismo no marketing ainda está engatinhando. Para POZZI (1998), até agora o Brasil tratou do futebol de forma romântica, espontânea e ingênua, mas nunca como um setor que pode gerar importantes ganhos financeiros e institucionais para o país.

Não há dúvida que, gerencialmente, os clubes e federações do futebol brasileiro não possuem a mesma hegemonia de dentro dos gramados. Como prova disso, temos diversos casos de instituições que são deficitárias além dos escândalos dentro do esporte.

$O$ fato de os clubes brasileiros de futebol apresentarem sistematicamente situação deficitária, que resulta em endividamento bancário, inadimplência fiscal e previdenciária, atrasos nas obrigações trabalhistas e nos salários dos jogadores, sugere a necessidade de aperfeiçoamento da qualidade da gestão dessas entidades.

O futebol possui um enorme potencial que, se for explorado com as ferramentas adequadas de marketing, agregará um grande valor aos clubes. Existem diversas 
oportunidades de marketing integradas aos objetivos da organização que são fundamentais para aumento das receitas e aproveitamento das oportunidades.

No futuro sobreviverão apenas os clubes que praticarem o seu marketing de forma eficaz. No Brasil, atualmente, são poucos os clubes que estão colocando em prática, planos e projetos de marketing (MELO NETO, 1998).

Melo Neto (1998) explica ainda que a receita financeira dos clubes não está sendo suficiente para cobrir seus gastos, deste modo, a saída para os clubes é um tipo de marketing voltado para as características de um clube como uma unidade de negócios.

Daí a idéia de Clube-empresa, ainda nova no Brasil, mas que alterou a configuração do futebol internacional através de um modelo de gestão esportiva e empresarial eficiente, o qual abordaremos a partir de agora.

Primeiramente abordaremos a inserção de empresas no esporte visto que, segundo Felipe (2011), a entrada das empresas no esporte começou com apoios financeiros para ajudar os clubes na contratação de jogadores. Como retribuição, a empresa tinha seu logotipo estampado na camiseta dos atletas. Estas serviam como veículo de divulgação da marca, não apenas nos estádios, mas, principalmente, por meio das imagens captadas pela televisão, pelos jornais e revistas.

A prática, apesar de absorvida pelo público, deu margem a opiniões divergentes sobre os efeitos de tais iniciativas no esporte enquanto fato social. As questões envolvidas nessa polêmica são três ameaças aos clubes: à identidade, à continuidade administrativa e ao equilíbrio técnico entre as equipes.

1. Identidade: Ao patrocinar uma equipe, as empresas passaram a exigir que sua marca fosse incluída no nome do clube, para colocá-la em maior evidência. Em muitos casos o nome original do clube cedia lugar a um nome de - fantasia.

2. Continuidade administrativa: $A$ instabilidade da permanência do patrocínio empresarial no esporte torna os clubes vulneráveis ante eventuais retiradas de apoio, e é outro fator que provoca reações críticas. Os empresários são acusados de usar o esporte como um bem descartável. Este tipo de critica, tráz implícito um julgamento sobre a responsabilidade que caberia ao clube de se esforçar para obter, com independência, os recursos necessários à sua sobrevivência, sem ter de se sujeitar às condições impostas pelo patrocinador.

3. Equilíbrio técnico: A canalização de recursos das empresas para um ou poucos clubes pode causar enorme desequilíbrio técnico entre as equipes, constituindo uma ameaça ao próprio esporte, pelo desinteresse que a falta de competitividade pode gerar. Essa concentração pode, ainda, desembocar numa transposição, para o âmbito esportivo, da guerra de mercado entre empresas concorrentes.

O marketing virou sinônimo de técnica de iludir o consumidor, dando uma maior percepção de relevância da marca. Não apenas o consumidor de produtos tradicionais, 
bens tangíveis (mercadorias) ou intangíveis (serviços e direitos), mas também o consumidor de produtos mais sutis, como as idéias e imagens - vendidas em ações de apoio a setores comunitários, em patrocínio a atividades de interesse social, em campanhas políticas dentre outros.

Dentre as áreas de atuação, no Brasil, Rezende (2000) apresenta, sob a ótica da organização como unidade social, dois grandes grupos: aquelas organizações que existem em função da atividade física, esportiva e de lazer - centros de treinamento e escolinhas; academias; clubes e associações exclusivamente esportivas; consultorias e assessorias; ligas, federações e confederações; fundações, instituições e comitês, entre outros - e aquelas que possuem setores voltados para a atividade física, desportiva e de lazer - prefeituras, governos estaduais, governo federal, clubes sociais, entidades representativas (SESC, SESI e outras).

Feita essa abordagem geral a respeito da participação das empresas no esporte, podemos discorrer sobre o assunto de maior interesse, o marketing nos clubesempresa: para isso é necessário estabelecer alguns pontos chave a respeito deste assunto. Aqui, o objetivo é analisar o desempenho esportivo de um clube e a influência de todo o serviço operacional de gestão estratégica e marketing de patrocínio que envolve um clubeempresa.

Nos últimos anos uma série de perguntas vem sendo feitas, mas faltam estudos e trabalhos científicos de natureza contemporânea para que se obtenham todas as respostas. Algumas questões podem explicar o que são clubes empresa e como é o funcionamento dos mesmos, como, por exemplo, até que ponto um clube deve priorizar uma única competição? O que é mais importante para a gestão do clube: acumular títulos ou maximizar os lucros? Qual a relação existente entre o desempenho esportivo e o desempenho econômico-financeiro do clube?

NETO (1998) afirma existir um novo paradigma a ser adotado pelos nossos clubes. Há quem diga ser o único caminho para a sobrevivência do esporte e a viabilização dos negócios esportivos. Deste modo, busca-se identificar a relação dos fluxos financeiros e a performance esportiva, a fim de otimizar os resultados do processo de gestão da entidade e proporcionar a simetria informacional dos gestores e demais usuários da informação (PEREIRA, C.A, et.al. 2003). Os clubes necessitam de se adaptar às mudanças do esporte e às exigências do mercado.

Com o fim do passe proposto pela Lei Pelé, houve uma redução do volume de receitas oriundas das negociações dos atletas pelos clubes brasileiros. Os chamados direitos liberatórios eliminam a figura do passe e dão maior liberdade ao jogador para negociar seu contrato. Com esta perda significativa nas receitas oriundas das transações de 
jogadores surge a necessidade de estudar mecanismos para maximizar os lucros e a gestão dos clubes (PEREIRA, C.A, et.al. 2003).

Outro problema é o amadorismo dos gestores que administram o clube levandose mais pela emoção ou paixão, como um simples torcedor, do que pela razão. Assim, Pereira (2003) afirma que os clubes necessitam cada vez mais adotar um sistema de informações que possa oferecer subsídios e auxiliar a tomada de decisão. Tal necessidade é corroborada por EDWARDS apud KFOURI (2000), quando o presidente do Manchester United afirma que contratar um jogador sem obedecer a qualquer orçamento e sem saber se seus salários poderão ser pagos é um exemplo típico de decisão com base na emoção.

Em contra partida, a venda de craques é um bom negócio que pode ser exemplificada com o caso do jogador Ronaldinho. Pereira et.al. (2003) cita que, conforme divulgado no IOB - TC (2001) em 1992, o passe do jogador foi comprado pelo Cruzeiro de Minas Gerais por US\$45 mil, e, em sua penúltima transferência, foi vendido do Barcelona ao Internazionale de Milão por um valor estimado entre US\$28 milhões e US\$34 milhões. Desta forma, percebe-se claramente que estes ativos podem ser considerados como elementos que fomentam a atividade econômica dos clubes.

Podemos citar dois processos de transformação a que os clubes devem se sujeitar para se tornarem empresa: um utilizando de modernas técnicas de gerenciamento e outro alterando os estatutos do clube e transformando em sociedade comercial. São eles: 1) o nível de gerenciamento, a empresarização do clube; 2) o nível legal, o que consiste a transformação do clube em uma da formas previstas pela Lei n.o 9.615, de 24/03/98, e o Decreto de Regulamentação n.o 2.574, de 29/04/98, a Lei Pelé (MELO NETO, 1998).

Segundo Hawilla (1990), um dos aspectos mais importantes na atual administração de empresas, a gestão mercadológica, tem um tratamento de segundo nível no futebol. Hoje, no Brasil, o dinheiro oriundo das bilheterias em dia de jogos, juntamente com o pagamento da mensalidade do associado, representam a principal fonte de renda dos clubes, não sendo trabalhados, prioritariamente, os principais ingressos da atividade de Marketing, os patrocínios, transmissões de jogos e licenciamento de marcas e franquias.

Para Suzuki (1997) a desorganização do futebol brasileiro é o fator determinante para que as empresas restrinjam a exposição de suas marcas nas camisas dos clubes. Embora quase todos os clubes de futebol profissional tenham patrocínio e o volume de negócios tenha evoluído nos últimos tempos, isso ainda representa um volume muito pequeno de investimentos em relação ao grande número de pessoas envolvidas direta e indiretamente com o futebol. O exemplo dessa desorganização é o calendário anual do esporte. Uma das maiores fontes de renda do futebol, os direitos de transmissão televisiva e as parcerias concretizadas através deles não são aproveitados como deveriam. Segundo Fernandes (2000), a irracionalidade dos calendários com campeonatos estaduais, brasileiro 
e internacionais, mais a Copa do Brasil e, associados a isso, os torneios patrocinados pelas próprias emissoras de televisão, gerando uma grande oferta de jogos transmitidos, podem acarretar queda na audiência a médio e longo prazos, associados ao imediatismo com a negociação dos direitos de televisão, ponto no qual os clubes perdem as maiores fontes de renda.

Suzuki (1997) afirma ainda haver uma necessidade incontestável de mudar este estado, deixar de lado a paixão clubística e adotar a postura empresarial, modernizar os clubes e transformá-los em empresas como pode-se observar em alguns exemplos pioneiros, no Brasil, de clubes que venderam suas ações ou fizeram grandes parcerias com empresas. Isso já pode ser constatado na transformação do E.C. Bahia em Sociedade Anônima, com a compra de $51 \%$ das ações do clube pelo Banco Opportunity, que passa a assumir o controle acionário e administrativo do clube - para fins de negócio, o valor patrimonial do clube foi avaliado em $\mathrm{R} \$ 18$ milhões; o contrato de parceria entre o Fundo de Investimentos Norte-Americano Hicks, Muse, Tate \& Furst (HMTF) com o Sport Clube Corinthians Paulista e Esporte Clube Cruzeiro de Minas Gerais em negócios acima de US\$ 100 milhões e, ainda, a parceria entre a empresa Suiça de Marketing Esportivo International Sports Leisure (ISL) com o Clube de Regatas Flamengo do Rio de Janeiro e com o Grêmio Futebol Porto Alegrense do Rio Grande do Sul; a aquisição do E.C. Lousano Paulista pela multinacional Parmalat e a transformação deste em Etti Jundiaí Futebol Ltda.

No entanto, Fernandes (2000) afirma que, o ritmo em que os clubes se transformarão em empresas não determinará o lançamento de novos produtos no mercado, mas a eficiência administrativa e esportiva é que levará a uma vantagem sobre seus concorrentes. A rentabilidade será maior para aqueles que centrarem sua atenção, mais rapidamente, no poder de compra do seu torcedor/cliente e determinarem estratégias mais criativas para o mercado esportivo.

O clube-empresa precisa competir em um mercado de produtos selecionados. $\mathrm{O}$ produto futebol vai exigir do clube-empresa a determinação de formas estratégicas de competição. A forma específica para competir será, geralmente, caracterizada por uma ou mais áreas funcionais estratégicas como, por exemplo: estratégia de linha do produto; posicionamento estratégico; estratégia de preços; distribuição estratégica; fabricação estratégica; informação tecnológica estratégica e segmentação estratégica (FERNANDES, 2000).

Para Pozzi (1998), o Grêmio Futebol Porto Alegrense é um exemplo de utilização de estratégia de marketing muito bem administrada. Dedica-se ao associado/torcedor como segmento de mercado, usa o slogan -Grêmio: 6.000.000 de clientes satisfeitos; a estratégia de linha de produto, como camisetas, transformou o time no que mais vendeu camisetas no mundo em 1996, e, com o licenciamento de produtos, 
possui mais de 250 produtos licenciados segundo site oficial do clube. Também as lojas do Grêmio Mania são um exemplo de estratégia de distribuição.

Especificamente no futebol brasileiro existem algumas vantagens competitivas sustentáveis que devem ser exploradas em seu máximo para que os clubes atinjam o resultado desejado de sucesso. Uma das maiores, se não a principal vantagem competitiva do nosso futebol é a sua grande capacidade de produzir craques. A cada ano, em todos os clubes de futebol do país, surge um grande número de novos jogadores, o que incrementa o espetáculo.

Posteriormente temos as habilidades e ainda a marca. A análise do clube como empresa resulta em uma constatação do bem maior que é a marca e a comercialização dos produtos que a ostentem, principalmente nos grandes clubes brasileiros. Uma pesquisa realizada pela consultoria Sirotzky \& Associadas estima que a marca Flamengo vale $R \$ 280$ milhões (Fernandes,2000).

Ou seja, existem várias fontes de receitas para os clubes, e o Brasil é privilegiado nesse contexto. No entanto, cabe aos dirigentes saber explorar essas fontes, como o patrocínio, as vendas, a comercialização da marca, a exploração econômica do patrimônio social dentre outros, sempre de forma profissional e utilizando de novos paradigmas como a gestão empresarial. Isto porque a possibilidade de implementação de novos paradigmas no futebol profissional apresentou significativos resultados do ponto de vista esportivo e econômico. Pode-se afirmar que a maioria dos clubes que alteraram seus modelos de gestão, em curto ou médio prazo, obtiveram êxito esportivo e econômico, pelo menos enquanto tal política foi adotada.

Enfim, é imprescindível que neste novo panorama sejam elaboradas normas especificas que disciplinem o clube empresa, semelhante à experiência européia, sobretudo no que concerne à sistemática de sua criação e estruturação, responsabilidade perante terceiros, transparência e lisura na gestão do negócio e, por fim, previsão quanto às hipóteses de extinção ou encerramento das atividades e seus desdobramentos. 
A coleta de dados se deu através de questionário semi estruturado de pesquisa qualitativa. Foram realizadas entrevistas com os gestores de marketing esportivos: Antonio Bernardo Albuquerque, CEO da Jogue Bola - Futebol \& Marketing; Fabio Monterosso, Ex Gerente de Negócios do Botafogo Futebol e Regatas e atual Coordenador de Marketing da Rio Eventos; Bruno Spindel, Diretor de Marketing do Clube de Regatas do Flamengo; João Pedro Mattar, Gerente de Marketing do Clube de Regatas do Flamengo e Roberto Rodrigues, Diretor Comercial na Deponta Marketing Esportivo. Os gestores das corporações do segmento desportivo apresentaram suas impressões sobre o retorno proporcionado e o retorno esperado com essa parceria. Foram entrevistados 5 executivos do esporte com entrevistas em profundidade, onde puderam expor o que sentem do mercado. As entrevistas foram feitas pessoalmente em seus respectivos locais de trabalho dos mesmos com gravação em áudio para uma melhor análise.

O questionário semi estruturado utilizado na elaboração da pesquisa qualitativa realizada através de entrevista presencial com os gestores de marketing esportivo contou com as seguintes perguntas:

1) Onde trabalha atualmente e cargo.

2) Descreva sua experiência no esporte.

3) O que acha do esporte/futebol?

4) Como você vê o mercado de patrocínios no futebol brasileiro atualmente?

5) Como você vê o mercado de patrocínio no futebol mundial atualmente?

6) Cite um exemplo de sucesso de ativação de patrocínios no Brasil e por que.

7) Cite um exemplo de sucesso de ativação de patrocínios na Europa e por que.

8) Qual o objetivo de uma empresa ao patrocinar o esporte no seu ponto de vista?

9) E o que a empresa espera obter desse patrocínio?

10) As empresas brasileiras buscam formas de ativação quando buscam patrocinar?

11) Quais são os indicadores utilizados pelas empresas para mensurar os resultados do patrocínio esportivo?

12) Cite 10 marcas que patrocinam o futebol no Brasil.

13) Você seria mais inclinado a comprar um produto caso o patrocinador patrocinasse o seu clube/esporte?

14) Na sua opinião, qual o principal motivo que a união consumidor / patrocinador é um sucesso? 


\subsection{Tratamento dos Dados}

Para fins de tratamento de dados foi utilizada na pesquisa qualitativa a categorização simples, que permitiu compreender os motivos que levaram as organizações pesquisadas a patrocinar as equipes de futebol em questão, quais os objetivos que as empresas pretendem atingir com essa parceria, qual o papel do marketing nessa relação, entre outros fatores determinantes para a continuidade de uma relação simbiótica entre patrocinador e patrocinado no que tange ao apoio aos clubes de futebol e aos demais esportes.

\subsection{Limitações da Pesquisa}

Como limitações de pesquisa podem-se destacar três pontos fundamentais.

Um dos fatores que dificultou a efetivação da pesquisa foi o fato de as empresas patrocinadoras não fornecerem informações através das entrevistas, alegando que são informações de estratégia e que as mesmas eram confidenciais.

Outro ponto que impediu a perfeita realização dessa pesquisa foi a dificuldade de se contatar os responsáveis pelo marketing das empresas patrocinadoras. Quando o contato com a empresa era possível, o responsável pelas decisões de marketing esportivo não sabia precisar a efetividade das ações em relação ao investimento realizado em patrocínio.

Como limitação de pesquisa, podemos citar, também, o tempo disponível dos profissionais para o encaixe na agenda, onde o número de entrevistados foi menor do que o que se esperava para este estudo. 
À partir da elaboração de entrevistas com gestores de entidades esportivas, pode-se observar que os esportes, por trabalharem com o apelo emotivo a seus torcedores, possibilitam a criação de uma estreita relação de empresas patrocinadoras com as paixões e ideais desses torcedores. Assim, proporcionam uma forte oportunidade mercadológica para empresas investirem no segmento esportivo, visto que empresas que investem em esporte, por fazerem um bem sócio-cultural levando lazer, são bem vistas com simpatia pelo público e consumidores. Como atesta João Pedro Mattar:

Acredito que o esporte englobe valores positivos à sociedade (saúde, respeito, disciplina, bem estar, etc.) e ao patrocinar o esporte, as empresas buscam associar suas marcas a esses valores, além, é claro, de obter uma maior exposição midiática, proveniente do espaço dado hoje ao esporte.

Para Bruno Spindel, Diretor de Marketing do Flamengo, e Roberto Rodrigues, diretor comercial de esporte e entretenimento na Deponta, a grande exposição proporcionada pelo esporte é capaz de gerar alguns valores que são propostos por Aaker em seu modelo de geração de valor por parte da marca, como: conexão emocional, associação à marca e fidelidade do espectador com as marcas. Como afirma Bruno Spindel:

O torcedor/consumidor/cliente está em um momento de lazer, prazer, diversão, emoção e ele recebe aquela mensagem de uma forma subliminar porque ele está exposto aquela visibilidade ou ele pode associar aquela marca a um momento de prazer dele. Eu realmente defendo o investimento no esporte por todos os atributos positivos que o esporte traz, além de estar associado a uma melhor qualidade de vida também.

Segundo o Gerente de Marketing do Clube de Regatas do Flamengo, João Pedro Mattar, como em qualquer tipo de patrocínio, em qualquer segmento, a empresa que patrocina o esporte busca melhores resultados para seu negócio, seja ele qual for. Para alcançar os objetivos pretendidos com o patrocínio, a empresa espera uma entrega eficaz por parte do clube/instituição patrocinada, com ativações frequentes que relacionem sua marca aos valores do esporte e, consequentemente, ao público consumidor. Contudo o mercado de patrocínio esportivo brasileiro aproxima-se a um mercado de anunciante e não 
um mercado de patrocínio, porém vem apresentando grande desenvolvimento. No entanto, a mentalidade mercadológica e a estrutura esportiva brasileira ainda afastam o cenário atual do cenário desejado, estando alguns degraus abaixo do mercado de patrocinio mundial (notadamente na Europa e nos EUA). Estes mercados que contam com uma estrutura comercial sólida e uma percepção de negócios "ganha-ganha" entre clubes, patrocinadores, veículos de imprensa e televisão. E que têm segurança para investir em contratos mais longos, com valores mais elevados, atrelados à possibilidade de uma efetiva associação de suas marcas aos clubes patrocinados e seus consumidores.

Tal disparidade entre mercados se deve em parte à ausência de uma análise interna, mais técnica, específica e objetiva por parte das empresas para mensurar seus resultados mercadológicos durante o período em que ocorrem as atividades de patrocínio. Como complemento aos números de exposição de marca, assim, ocorre uma redução da percepção do real benefício do patrocínio esportivo. Por isso, clubes e empresas devem buscar contratar os serviços de empresas como a lbope/Repucom para realizar a mensuração do retorno de visibilidade de marca nas diversas propriedades de visibilidade utilizadas pelas empresas em seus patrocínios.

João Pedro Mattar ressalta, ainda, que a estruturação de um mercado de patrocínio é um processo lento de conscientização, relacionamento, testes e de demonstração de resultados, que precisa ser constantemente trabalhado junto às empresas parceiras para a obtenção de relações mais sólidas de patrocínio com clubes e empresas no médio prazo, explorando assim, o real potencial da associação de marcas e do relacionamento no futebol. Hoje em dia é cada vez mais comum agências de publicidade e departamentos de marketing de clubes busquem o desenvolvimento conjunto de ações criativas, propostas de ativações e iniciativas de engajamento partindo dos patrocinadores que gerem resultados positivos para ambos os lado.

Com base nos relatos dos entrevistados, torna-se evidente a suma importância da aplicação das estratégias de marketing, com base em estudos e analises para o desenvolvimento do segmento esportivo, por isso, tanto clubes como assessorias de atletas devem buscar se profissionalizar através da criação de uma organização e planejamento eficaz, de forma a otimizar seus recursos para a consolidação de resultados condizentes com os investimentos realizados e, assim, valorizar sua imagem comercial, atraindo maiores patrocínios.

A partir das entevistas, pode-se notar, também, que apesar do intenso crescimento do cenário esportivo nacional, ainda há um baixo grau de especialização de clubes em marketing esportivo, necessitando uma maior profissionalização do setor de merketing dessas instituições, de maneira a organizar e otimizar a utilização dos recursos 
providos por meio de patrocínio, fazendo com que os retornos sobre o investimento em patrocínio sejam, por sua vez, cada vez mais atrativos.

Pelo conteúdo adquirido na pesquisa semi-estruturada, pode-se constatar que os métodos de mensuração e controle dos dados relacionados aos objetivos de marketing ainda são precários, necessitando maior modernização a partir do desevolvimento e aprimoramento das plataformas de gestão dos clubes e dos órgãos de pesquisa, no que se refere ao segmento esportivo. Assim, clubes poderão ter maior controle de índices como, número de associados, público pagante, faturamento de franquias, número de produtos vendidos e, portanto, o retorno sobre o investimento. Essa atitude de maior precisão propiciará um aumento da prática das atividades de patrocínio. Como constata João Pedro Mattar:

Clubes e empresas comumente contratam os serviços de empresas como a Ibope/Repucom, que faz a mensuração do retorno de visibilidade de marca nas diversas propriedades de visibilidade utilizadas pelas empresas em seus patrocínios. Contudo, a falta de uma análise interna, mais técnica, específica e objetiva por parte das empresas para mensurar seus resultados mercadológicos no período do patrocínio, como complemento aos números de exposição de marca, reduz a percepção do real benefício do patrocínio esportivo.

Com base na precariedade dos métodos de mensuração, destaca-se, também, o baixo investimento dos setores de marketing das instituições esportivas em estratégias de marketing de ativação de patrocínio, notando-se, assim, a realização de ações de divulgação publicitaria figurando como marketing de ativação. Como afirma Antonio Bernardo Albuquerque, CEO da Jogue Bola - Futebol \& Marketing:

Hoje em dia as empresas que buscam o patrocínio estão começando a ver o lado da ativação, mesmo que lentamente. $\mathrm{Na}$ realidade elas buscam agências de publicidade para que ajudem nas ideias e desenvolvam algum pacote interessante de patrocínio e que sua verba seja melhor investida dentro do contrato.

A seguir, alguns pontos relevantes abordados nas entrevistas:

- Os Entrevistados apresentam forte envolvimento com o esporte, mais especificamento com o Futebol, não só pessoal e emocionalmente como torcedores, mas também profissionalmente como gestores de clubes e/ou de empresas de marketing esportivos relacionadas a clubes. 
- O mercado de patrocínio esportivo vem se desenvolvento fortemente, apresentando franco crescimento no Brasil, porém longe de um nível ideal, muito abaixo do nível internacional, visto que a estrutura do futebol brasileiro não favorece a concepção do cenário desejado, uma vez que se necessita de uma maior profissionalização do marketing dos clubes, um maior incentivo das marcas e uma lesgilação mais clara quanto à regulamentação das atividades de patrocínio, enquanto o futebol internacional, mais especificamente o futebol europeu, já apresenta uma estrutura comercial sólida com uma percepção de negócios ganha-ganha que favorece sinergicamente clubes, patrocinadores, marcas e veículos de imprensa.

- Pode-se observar através de exemplos pontuais de ativação de patrocínio, que empresas que investem em ativação de marca apresentam retornos extraordinários tanto para as marcas patrocinadoras quanto para o clube patrocinado. Como exemplo podemos citar o caso de sucesso entre Palmeiras e Parmalat nos anos 90 e Manchester City e Etihad Airways atualmente.

- Ao estabelecer a prática de patrocínio uma empresa visa, a partir da associação positiva entre valores sociais aos valores da marca e do esporte, obter maiores retornos, melhor percepção e, portanto, melhores resultados para o negócio.

- Atualmente, o marketing esportivo trabalha a ativação de marca não só por meio das mídias convencionais, mas também muito fortemente das mídias digitais através da geração de conteúdo programático nas redes sociais, jogos de vídeo game, canais de vídeos dentre outras plataformas complementares.

- As empresas que investem em atividades de ativação de marca buscam medir a efetividade de suas ações de marketing esportivo através da contratação de serviços de empresas como IBOPE, REPUCOM e DATA FOLHA. A partir de estudos elaborados por essas empresas, mensura-se o retorno de viabilidade de marca nas diversas propriedades de visibilidade utilizada nas atividades de publicidade das marcas patrocinadoras. No entanto a análise interna precária em mensurar os resultados mercadológicos durante o período da pratica do patrocínio reduz a percepção do real beneficio do patrocínio esportivo. 
Torna-se evidente a importância do marketing esportivo para o desenvolvimento tanto dos esportes quanto das marcas. O crescimento dos estudos científicos nesse ramo e sua aplicação em todas as áreas, mas principalmente no esporte, comprova a importância de tal segmento.

O Marketing esportivo transformou o espetáculo em um ótimo negócio. Aumento do número de espectadores, de patrocínios, cifras bilionárias são apenas exemplos de sua influência.

Valores das marcas são imprecindiveis na concepção das atividades de patrocínio que envolve ativações, visto que as marcas através dessas atividades buscam obter a conscientização, associação e fidelidade à marca por parte do espectador, que é um potencial consumidor dos produtos da marca que realiza o patrocínio.

Atualmente, falar em clube ou atleta sem planejamento, que não se organiza e não possui uma assessoria de marketing é sinal de retrocesso e amadorismo, visto que é inviável competir em um mercado cada vez mais disputado. Os resultados, principalmente em clubes de futebol europeus, vêm ratificar essa afirmativa.

No Brasil ainda são poucos os especializados em Marketing Esportivo. Uma área em intenso crescimento dentro do cenário esportivo nacional, mas que ainda não surte os efeitos provocados no marketing no exterior devido a falta de profissionalismo e organização de nossos gestores e dirigentes.

A alternativa de transformar clubes em empresas é uma saída encontrada e vinda da Europa, mas que, no Brasil, não se concretizou como melhor forma de gestão. Os recentes estudos e dados divulgados e citados ao longo desde trabalho, nos mostram que, apesar da melhoria das gestões e aumento do profissionalismo e especialização dos responsáveis pelo esporte, ainda é lento o processo de mudança no Brasil. Estamos começando a colher os frutos de um investimento em Marketing.

Portanto, empresas ou clubes que desejam manter-se competitivas no mercado do século XXI, precisam investir em imagem, marketing, promoção da marca, especialização e ativação de suas marcas. 


\section{Referências bibliográficas}

AAKER, David A. "Administração Estratégica de Mercado". Porto Alegre: Bookman, 2001. AAKER, David A. "Building Strong Brands". New York: The Free Press, 1996.

AAKER, David A. "Managing Brand Equity: Capitalizing on the Value of a Brand Name". New York: The Free Press, 1991.

AAKER, David A.; JACOBSON, Robert "The Financial Information Content of Perceived Quality". Journal of Marketing Research, Maio 1994, pp. 191-201.

AAKER, David. Marca: brand equity, gerenciando o valor da marca - 2a edição, São Paulo: Negócio Editora, 1998.

ANDERSON, Eugene W; FORNELL, Claes e LEHMANN,Donald R., "Customer satsfaction,Market share and profitability: findings from Sweden", Journal of Marketing, July 1994.

BENNETT, R. Sports sponsorship, spectator recall and false consensus. European Journal of Marketing, v.33, n.3/4, p. 291-313, 1999.

CORNWELL, T. B.; MAIGNAM, I. An international review of sponsorship research. Journal of Advertising, v.27, n.1, p. 1-21, 1998.

CORNWELL, B.; WEEKS, S. C.; ROY, D. P. Sponsorship-linked marketing: opening the black box. The Journal of Advertising, vol. 34, n. 2, p. 21-42, 2005.

CROMPTON , J. Conceptualization and alternate operationalizations of the measurement of sponsorship effectiveness in sport. Leisure Studies, v.23, n. 3, p. 267-281, 2004.

CROWLEY, M. G. Prioritizing the sponsorship audience. European Journal of Marketing, v. 25, n.11, p. 11-21, 1991. DARDIS, F. E. Attenuating the Negative Effects of Perceived Incongruence in Sponsorship: How Message Repetition Can Enhance Evaluation of an "Incongruent" Sponsor. Journal of Promotion Management, vol. 5, issue 1/2, p. 36-56, 2009.

CUNEO, Alice, AdvertisingAge: Apple transcends as lifestyle brand, 2003. Disponível em: http://adage.com/article/special-report-marketer-of-the-year/apple-transcends-lifestylebrand/97129/, Acesso em 15/07/2015

D’ASTOUS, Alain; BITZ, Pierre. Consumer evaluations of sponsorship programmes. European Journal of Marketing, v. 29, n.12, p. 6-22, December 1995.

FAHY, J.; FARRELY, F.; QUESTER, P. Competitive advantage through sponsorship: a conceptual model and research propositions. European Journal of Marketing, v.38, n.8, p. 1013-1030, 2004.

FARRELLY, F.; QUESTER, P. Examining important relationship quality constructs of the focal sponsorship exchange. Industrial Marketing Management, v. 34, n. 2, p. 211-219, 2005. FIFA. Disponível em: www.fifa.com/aboutfifa/marketingtv.html. Acesso 09-03-2008.

LACERDA, Felipe. Panorama do Marketing Esportivo no Brasil, UFMG.Belo Horizonte, 2011.

GROHS, Reinhard; WAGNER, Udo; VSETECKA, Sabine. Assessing the effectiveness of sport sponsorships: an empirical examination. Schmalenbach Business Review, v.56, p. 119- 138, April 2004. 
HENSELER, J.; WILSON, B.; DE VREEDE, D. Can sponsorship be harmful for events? Investigating the transfer of associations from sponsors to events. International Journal of Sports Marketing \& Sponsorship. Apr., p. 244-251, 2009.

JAVALGI, R.; TRAYLOR, M.; GROSS, A.; LAMPMAN, E. Awareness of sponsorship and corporate image: an empirical investigation. Journal of Advertising, v. 23, n.4, p. 47-58, dec. 1994.

KELLER, K. L. Conceptualizing, measuring, and managing customer-based brand equity. Journal of Marketing, v. 57, pp. 1-22, 1993.

MEENAGHAN, J. A. Commercial Sponsorship. European Journal of Marketing, v.17, n.7, p. 5-69, 1983.

MEENAGHAN, T. Sponsorship: legitimizing the medium. European Journal of Marketing, v. 25, n.11, p. 5-10, 1991.

MICHAELIS. Dicionário Escolar da Língua Portuguesa. São Paulo: Editora Melhoramentos, 2002. NARDONE, J.; SEE, E.; Measure Sponsorships to Drive Sales. Advertising Age, v.78, n.10, p. 20-21, 2007.

AFIF, Antônio. A Bola da Vez - o marketing esportivo como estratégia de sucesso. São Paulo. Editora Infinito, 2000.

CONTURSI, Ernani. B; Marketing Esportivo. 2o edição. Rio de Janeiro: Sprint.1996 COSTA, L. P. Diagnóstico da Educação Física/Desportos no Brasil. Rio de Janeiro:

FORD, Henry. Minha vida e minha obra. Rio de Janeiro, Nacional, 1926. FREIRE, Marcos Vinicius , Ouro Olímpico; A história do marketing dos aros.

Jornal ZERO HORA, Porto Alegre, 13 de dezembro 1998, Caderno de Economia, p. 04.

KEARNEY, A.T. O jogo está começando. HSM Management. São Paulo, v.. 4, n. 39, p. 3646, jul./ago. 2003.

KOTLER, Philip, Administração de Marketing. S.Paulo. Atlas. Vol I

KOTLER, Philip, ARMSTRONG, Gary. Princípios de Marketing. Rio de Janeiro: PrenticeHall do Brasil Ltda, 1993.

KOTLER, Philip. Marketing, São Paulo: Atlas, 1998.Administração de Marketing. São Paulo: Prentice Hall, 2000.

KOTLER, Philip. KELLER, Kevin. Administração de Marketing - 12a Edição. São Paulo: Prentice Hall, 2006.

MORAES et alli In: Anais Congresso de Iniciação Científica e Simpósio de Pós- Graduação, 6/4. São Paulo: EEFEUSP, 1999. p. 108-109

MELO NETO, Francisco Paulo de. Marketing no esporte. Rio de Janeiro: Incentive,1986. Marketing Esportivo. Rio de Janeiro, Record, 1995.

Projetos de marketing esportivo e social. Londrina, Midiograf, 1997.

Administração e Marketing de clubes esportivos. Rio de Janeiro, Sprint, 1998b. 
Marketing de Eventos. Rio de Janeiro, Editora Sprint Ltda, 1998a.

Administração e Marketing de Clubes Esportivos. Rio de Janeiro, Ed. SPRINT, 1998.

Marketing de Patrocínio. Rio de Janeiro,Sprint, 2003. GRACIOSO, Francisco. Marketing. São Paulo: Atlas, 2005

MEENAGHAN, Tony. The Role of Sponsorship in the Marketing Communication Mix, International Journal of Advertising, n.10, pág.35.47.1991.

PEREIRA, C.A. et.al. A gestão estratégica de clubes de futebol: Uma análise da correlação entre performance esportiva e resultado operacional. 2003.

PITTS, B. B.; STOTLAR, D. K. Fundamentos de marketing esportivo. São Paulo: Phorte, 2002.

POZZI, L., OLIVEIRA, M. Patrocine o Evento Certo. Mercado Global. São Paulo, n.99, p.13.15. 1996.

POZZI, Luis Fernando. A grande jogada: Teoria e Prática de Marketing Esportivo. SP: Globo, 1998.

REZENDE, J.R. Organização e administração no esporte. Rio de Janeiro, Sprint, 2000. Revista Marketing, S.Paulo Referencia ${ }^{\circ} 174$

SANTOS, Tarcyane C. Dos espetáculos de massa às torcidas organizadas: paixão, rito e magia no futebol. São Paulo, 1998. Tese (Mestrado em Ciências da comunicação) - ECAUSP.

SANTOS, Eugenio Andrade Vilela. Marketing Esportivo: Análise de investimentos no futebol brasileiro. Unitri, 2002.

SOARES, M.L. Identificação das barreiras e facilitadores que influenciam na elaboração da estratégia de marketing esportivo nos clubes de futebol no Brasil - Estudo de caso do Grêmio Futebol Porto Alegrense. Unipar. 2005.

SOBRINO, Luísa. Avaliação de marcas pelo método do fluxo de caixa descontado, IBMECRJ.Rio de Janeiro, 2014.

TEITELBAUM, I . Marketing esportivo. Um estudo exploratório. Porto Alegre. 1997.

MACHADO, Jefferson Roberto; ZEM, Carlos Alberto. Marketing Esportivo: Um Estudo Sobre o Crescimento das Instituições de Ensino na Prática do Patrocínio Esportivo. Unimep, Piracicaba, 2003. Disponível em: www.ead.fea.usp.br/Semead/7semead/paginas/marketing completo, Acesso em $18 / 10 / 2015$.

Tendência na mudança de instalações de propósito único para instalações multiuso. (http://www.boasideias.com.br/guiadomarketing/canal tipos de marketing/Esportivo.htm). 